\title{
PENGEMBANGAN USAHA KULINER "WAROENG MAKAN TEPI LAUT" DI KAWASAN MEGA MAS, KOTA MANADO
}

\author{
Angraini Datunsolang \\ Jenny Baroleh \\ Benu Olfie L.S.
}

\begin{abstract}
This study aims to describe how the development of a culinary efforts and make an assessment as the basis to determine the culinary business development. This study began in March until June 2016. This research located in "Waroeng Makan Tepi Laut", Kawasan Mega Mas, Kota Manado. The data collected in this research included primary data and secondary data. The primary data obtained from interviews with managers, managers and employees. And also interview based questionnaire on the visitors / customers as many as 15 people. Secondary data was collected from the Office of Administration "Waroeng Makan Tepi Laut". The results of this study indicate that "Waroeng Makan Tepi Laut" has a strategic business location, the menu selection is varied, the prices offered can be affordable, quality service owned "Waroeng Makan Tepi Laut" is quite good, has a typical menu favored by the customers / visitors, ample parking location and stage music favored by the customers / visitors.
\end{abstract}

Key words: development, business culinary, Warung Makan Tepi Laut, Kota Manado

\section{ABSTRAK}

Penelitian ini bertujuan untuk melihat bagaimana perkembangan suatu usaha kuliner serta melakukan suatu kajian sebagai landasan untuk mengetahui pengembangan usaha kuliner. Penelitian ini di mulai pada bulan Maret sampai bulan Juni 2016, yang berlokasi di "Waroeng Makan Tepi Laut", Kawasan Mega Mas, Kota Manado. Data yang dikumpulkan dalam penelitian ini meliputi data primer dan data sekunder. Data primer diperoleh dari wawancara dengan pengelola, manajer dan karyawan. Dan juga wawancara berdasarkan angket pada pengunjung/pelanggan sebanyak 15 orang. Sedangkan data sekunder dikumpulkan dari Kantor Administrasi "Waroeng Makan Tepi Laut". Hasil penelitian ini menunjukkan bahwa "Waroeng Makan Tepi Laut" memiliki lokasi usaha yang strategis, pilihan menu bervariasi, harga yang ditawarkan dapat terjangkau, kualitas pelayanan yang dimiliki "Waroeng Makan Tepi Laut" cukup baik, memiliki ciri khas menu yang disukai oleh para pelanggan/pengunjung, lokasi parkir yang cukup luas dan panggung musik yang disukai oleh para pelanggan/pengunjung.

Kata kunci: pengembangan, usaha kuliner, Warung Makan Tepi Laut, Kota Manado

\section{PENDAHULUAN}

\section{Latar Belakang}

Manado merupakan salah satu kota metropolitan yang selalu sibuk dengan kegiatan ekonomi. Terlepas dari itu kegiatan dalam perbaikan pada infrakstruktur dan sarana pra sarana di Kota Manado membuat kegiatan ekonomi menjadi ramai lancar. Hal serupa juga dengan kemajuan pada sektor Perdagangan, Hotel dan Restoran, dimana perbaikan ini membuat konsumen selalu dapat menjangkau dengan mudah tempat yang ingin didatangi seperti restoran dan rumah makan, pasar serta hotel.
Industri pengolahan bahan pangan siap saji (Retoran dan Rumah Makan) merupakan tempat yang mudah dijangkau dan terdapat di setiap sudut kota baik kota besar maupun kota kecil dengan skala rumah makan, interior, pelayanan harga dan lain-lain yang berbedabeda. Rumah makan merupakan salah satu tempat yang banyak dikunjungi oleh konsumen.

Dalam perkembangannya rumah makan khususnya di Kota Manado mengalami pertumbuhan yang begitu pesat. Berdatangnya para pelaku usaha di bidang kuliner membuat usaha ini ada dimana-mana sehingga harus mampu bersaing.

Perkembangan usaha merupakan salah satu faktor yang dapat menentukan bagaimana usaha rumah makan dapat bersaing dan berjalan 
dengan baik. Pengembangan pada hakikatnya merupakan kajian yang selalu dilakukan oleh setiap pelaku usaha dalam mencapai tujuannya, karena salah satunya dari kegiatan restoran atau usaha kuliner sendiri mempunyai tujuan utama untuk mendapatkan keuntungan semaksimal mungkin (Nurahaman dalam Masengi, 2014).

Di Kota Manado ada begitu banyak rumah makan salah satunya adalah "Waroeng Makan Tepi Laut". Rumah makan yang sudah berdiri sekitar 5 tahun ini bertempat di Kawasan Mega Mas Kota Manado merupakan rumah makan yang berskala menengah dan diminati oleh masyarakat umum baik remaja, dewasa hingga orang tua. Rumah makan yang setiap malam sabtu dan malam minggu menghadirkan life musik ini merupakan tempat yang nyaman untuk makan dan bersantai serta terletak di tempat yang strategis. Usaha ini juga tidak lepas dari dunia persaingan serta harus mampu beradaptasi dengan lingkungan internal dan eksternalnya yang dimana lingkungan ini dapat berpengaruh positif maupun negatif terhadap pertumbuhan usaha.

Persaingan yang begitu ketat serta hadirnya pesaing-pesaing baru dalam dunia kuliner membuat pengelolah "Waroeng Makan Tepi Laut" selalu menghadirkan inovasi-inovasi baru agar usahanya tetap bertahan dan berkembang serta mampu bersaing dengan lingkungan usaha lainnya. Tak lepas dari itu setiap pengelolah usaha juga harus mampu menganalisis setiap kondisi yang dapat mempengaruhi usahanya seperti keunggulan apa yang dimiliki, apa yang dapat dimanfaatkan serta apa yang menjadi penghambat. Kondisi ini menuntut pengelolah usaha untuk mampu mengembangkan usaha ini menjadi besar, maju dan menguntungkan.

\section{Rumusan Masalah}

Berdasarkan latar belakang yang telah dikemukakan maka yang menjadi permasalahan dalam penelitian yaitu: Bagaimana pengembangan usaha kuliner "Waroeng Makan Tepi Laut" di Kawasan Mega Mas Kota Manado?

\section{Tujuan dan Manfaat Penelitian}

Tujuan dari penelitian ini adalah untuk melakukan suatu kajian sebagai landasan untuk mengetahui pengembangan usaha pada "Waroeng Makan Tepi Laut" di Kawasan Mega Mas Kota Manado.

Manfaat dari penelitian ini untuk memberikan informasi dan masukan kepada "Waroeng Makan Tepi Laut" dalam mengembangkan usaha serta penelitian ini dapat dijadikan sebagai bahan referensi untuk penelitian-penelitian yang terkait dengan dunia kuliner dan pengembangan usaha.

\section{METODOLOGI PENELITIAN}

\section{Waktu dan Tempat Penelitian}

Penelitian ini dilaksanakan pada bulan Maret sampai bulan Juni 2016 di "Waroeng Makan Tepi Laut" Kawasan Mega Mas Manado. Dimulai dari persiapan proposal penelitian, pengambilan data sampai ujian skripsi.

\section{Metode Pengumpulan Data}

Penelitian ini menggunakan metode accidental sampling dimana pengumpulan data diperoleh melalui data primer yang diperoleh melalui teknik observasi dan wawancara dengan menggunakan kuesioner dengan pihak-pihak terkait meliputi pengelola, manajer dan karyawan serta para pengunjung/pelanggan (angket diberikan pada 15 pengunjung/ pelanggan). Data sekunder dikumpulkan dari Kantor bagian Administrasi dari "Waroeng Makan Tepi Laut".

\section{Faktor-faktor Yang Diteliti}

Faktor Internal meliputi:

1. Bahan baku

2. Lokasi usaha

3. Bangunan usaha

4. Pilihan menu

5. Harga

6. Pelayanan

7. Ciri khas menu

8. Teknologi

9. Lokasi parkir

10. Panggung Musik

11. Promosi Produk

12. Layanan pesan antar

13. Sarana pra sarana

14. Cabang usaha.

Faktor Eksternal meliputi:

1. Mitra kerja

2. Berkembangnya sektor pariwisata 
3. Pesaing usaha sejenis

4. Kebijakan pemerintah

\section{Metode Analisis Data}

Metode analisi data digunakan analisis kualitatif deskriptif, dimana data yang terkumpul di deskripsikan dengan menggunakan tabel persentase secara rinci untuk mengetahui permasalahan dari penelitian.

\section{HASIL DAN PEMBAHASAN}

\section{Deskripsi Lokasi Penelitian}

Awal berdirinya "Waroeng Makan Tepi laut" adalah, sebuah Waroeng makan tradisional yang hanya menyediakan mie instan dan pisang goreng, oleh karena begitu banyak minat pengunjung maka dibuatlah beberapa menu untuk melengkapi. Seiring berjalannya waktu waroeng makan tepi laut semakin mengembangkan diri, yang awal berdiri hanya berukuran 1 ruko kini hadir lebih luas dan menghadirkan kenyamanan bagi pengunjung.

"Waroeng Makan Tepi Laut" hadir dengan membawa konsep masakan tradisional khas Minahasa, salah satu menu makanan yang diunggulkan adalah "bebek smart" yang diolah dengan campuran rempah-rempah khas Minahasa, bebek smart hadir dengan citarasa yang unik. Selain itu hadir juga makanan khas Minahasa lainya yaitu cakalang saus, abon cakalang, daging sapi garo rica, ayam goreng

rica, ikan teri tahu tempe kering, telur balado sebagai pelengkap sayur kangkung, sayur campur, sayur santan, sayur nangka tersedia di warung makan ini.

Dengan citarasa yang fresh para customer bisa langsung memilih aneka menu yang tersedia di display, selain itu menu minuman semakin lengkap dengan hadirnya beberapa minuman juice dari buah-buah yang segar seperti jus alpukat, semangka, apel, sirsak serta berbagai macam aneka minuman yang siap memanjakan lidah pelanggan.

Selain makanan dan minuman, "Waroeng Makan Tepi Laut" kini menyajikan aneka cemilan seperti : pisang goroho goreng tipis atau tebal, roti bakar, kentang goreng (mix snack), sebagai penutup tersedia juga salad buah keju, pudding, aneka buah segar.

Kini Waroeng Makan Tepi Laut hadir dengan konsep semi fast food di Kawasan Mega Smart 6 No. 20 kawasan Mega Mas. Kenyamanan semakin bertambah dengan dibukanya lantai 2, dengan view laut.

Nama usaha

Lokasi usaha

Tahun berdiri usaha Pemilik usaha
: Waroeng Makan Tepi Laut

: Ruko Mega Smart

No 19-20 Kawasan

Mega Mas

Kota Manado

: Tahun 2011

: Bpk M, Iqbal Suleman

\section{STRUKTUR ORGANISASI}

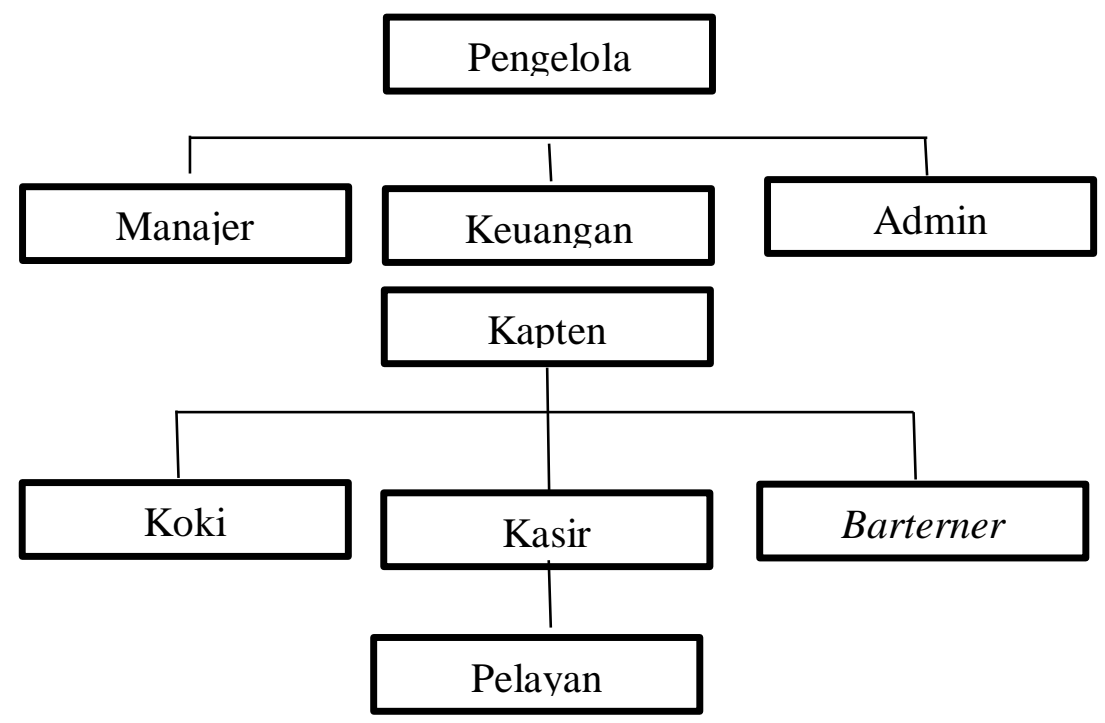




\section{Standar Operational Procedur (SOP) Waroeng Makan Tepi Laut}

Standar operational procedur (SOP) atau prosedur pelaksanaan dasar merupakan suatu ketetapan yang terstandar untuk mempertahankan kualitas dan hasil pekerjaan. Dampak SOP dalam Food \& Beverage Departement merupakan suatu hal yang sangat memudahkan pekerjaan karyawan dan menciptakan suasana yang membuat para pengunjung/pelanggan menjadi nyaman dan mendapatkan apapun yang diinginkan. SOP general service yang harus dilakukan oleh bagian service adalah:

1. Greeting the guest : pengunjung/pelanggan memasuki restoran disambut dengan ramah

2. Take the order: Memberikan buku menu kepada pengunjung/pelanggan, serta membantu pengunjung/pelanggan memilih makanan dan minuman yang di kehendaki.

3. Sudjestive selling: Menawarkan kembali menu yang ada, contoh; Makanan Penutup seperti Salad atau ice cream.

4. Repeat the order: Mengulang kembali pesanan pengunjung/pelanggan, supaya tidak terjadi kesalahan order.

5. Total, Collect The Money: Tugas selanjutnya dari seorang server adalah memberitahukan kepada pengunjung/ pelanggan jumlah makanan dan minuman yang harus dibayar.

\section{Waroeng Makan Tepi Laut (WATELA) SECTION}

Berikut ini merupakan bagian serta tugas-tuga para karyawan dari "Waroeng Makan Tepi Laut

\section{Kasir}

Kasir merupakan ujung tombak dalam memperoleh omset, tugas seorang kasir berhubungan langsung dengan pengunjung/pelanggan. Oleh karena seorang kasir wajib mengetahui semua menu yang ada, sehingga mampu menawarkan berbagai menu yang tersedia. Gunakan 5 step of service untuk mempermudah bertransaksi dengan pengunjung/pelanggan.

\section{Koki}

Tugas seorang koki adalah menerima pesanan dari kasir (made to order) serta membuat pesanan tersebut.

3. Drink person / bar

Tugas seorang drink person adalah menerima pesanan dari cashier (made to order) serta membuat pesanan tersebut.

4. Penyaji

Tugas penyaji adalah menyediakan pesanan sesuai dengan nota dari cashier, setelah semua pesanan komplit, akan diserahkan ke pelayan

5. Pelayan

Tugas pelayan adalah menerima pesanan pengunjung/pelanggan dari penyaji untuk selanjutnya di antar ke meja pengunjung/ pelanggan, selain itu pelayan mempunyai tugas membantu pengunjung/pelanggan saat dibutuhkan, seperti mengambil tissue, tusuk gigi dll. Tugas utama dari pelayan adalah melayani pengunjung/ pelanggan. Peralatan yang harus di siapkan oleh seorang Server saat melayani pengunjung/pelanggan adalah :
a. Pulpen
b. Captain Order
c. Menu

\section{Pengunjung/Pelanggan}
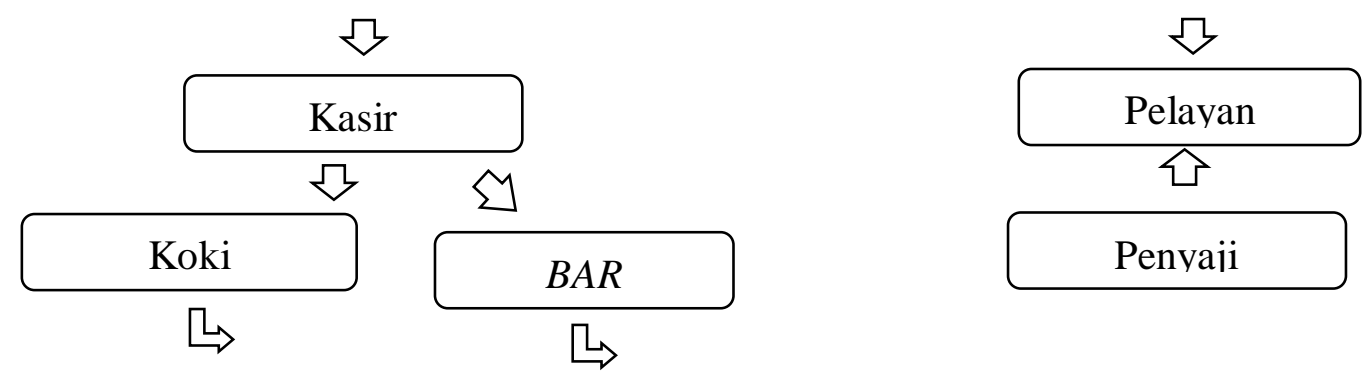
Karena pelayan berhubungan di tuntut memiliki persyaratan sebagai berikut:

\section{Ramah Tamah}

Sikap ramah tamah dan sopan santun merupakan hal yang harus selalu di perlihatkan oleh setiap karyawan seperti:

a. Menyambut pengunjung/pelanggan yang datang ke restoran

b. Memberikan pelayanan yang sama kepada setiap pengunjung/pelanggan tanpa membeda bedakan suku, agama, dan bangsa.

c. Membiasakan penggunaan ungkapanungkapan seperti: "selamat pagi", "silahkan", "selamat menikmati hidangan", "terima kasih" dan lain-lain.

d. Berusaha mengingat dan memanggil dengan menyebut nama pengunjung/ pelanggan, terutama kepada pengunjung/ pelanggan langganan.

e. Bersikap rela membantu dan melayani setiap pengunjung/pelanggan.

f. Menghindari kebiasaan menirukan dan mengoreksi sikap pengunjung/pelanggan yang berada di restoran.

g. Menghindari kebiasaan berteriak, bersiul dan mengunyah makanan pada waktu bertugas.

h. Menghindari merokok, bersin, berkumur, meludah atau kebiasaan lain yang tidak terpuji di hadapan pengunjung/pelanggan.

\section{Penampilan Diri setiap karyawan}

Hal ini sangat besar pengaruhnya dalam usaha memberikan kesan pertama yang baik kepada setiap pengunjung/pelanggan di restoran. Penampilan pribadi terdiri dari beberapa komponen sebagai berikut:

a. Rambut pria dicukur pendek sewajarnya, disisir rapih, tidak berkumis, jenggot, dan cambang (selalu dicukur). Rambut wanita tidak terlalu panjang, disisir rapih gunakan cepol dan tidak berponi, menggunakan make up yang sewajarnya, tidak menggunakan aksesories, kuku bersih dan pendek tidak menggunakan cat kuku, biasakan selalu mencuci tangan dengan sabun.

b. Gunakan sepatu hitam dan pantas dan menggunakan kaos kaki.

c. Selalu memperlihatkan sikap yang menyenangkan pada saat melayani pengunjung/pelanggan baik pada saat mengambil pesanan sampai pada saat melayani makanan yang dipesan. Tidak dibuat-buat/kaku, Luwes dan menarik, sopan dan tidak membosankan.

d. Gerak-gerik tidak dibuat-buat, hindari gerakan yang tidak perlu, gerakan pelayanan harus gesit tidak terkesan malas.

e. Gunakan pakaian seragam yang telah ditentukan, pakaian enak digunakan (tidak ketat, dll), harus selalu bersih, rapih dan berbau segar, tidak bernoda, kancing harus lengkap, atribut lengkap.

3. Prosedur menyiapkan pesanan dari pengunjung/pelanggan

Setelah server berkomunikasi secara langsung dan menerima orderan dari pengunjung/pelanggan, langkah selanjutnya adalah memproses pesanan tersebut, berikut prosedur yang harus dilaksanakan:

a. Captain Order yang sudah di isi pesanan pengunjung/pelanggan, diserahkan kepada kasir.

b. Kasir menginput ke POS (Point Of Sales)

c. Setelah selesai di input, kroscek kembali dengan cara cocokkan kembali dengan captain order dan harus sesuai.

d. Jika sudah yakin segera save, atau disimpan.

e. Buat cetak struk sementara.

f. 2 lembar struk yaitu putih dan merah, lembar putih untuk tagihan dan lembar merah di streples dengan captain order dan diserahkan ke penyaji.

g. Struk berwarna putih, untuk selanjutnya oleh pelayan akan diberikan kepada pengunjung/pelanggan sebagai bukti tagihan.

h. Struk berwarna Merah, akan segera diproses oleh penyaji, setelah selesai ceklist dan pelayan untuk mengantarkan pesanan pengunjung/pelanggan.

i. Simpan kertas struk yang berwarna merah.

4. Prosedur yang harus dijalankan seorang kasir

a. Menerima kembali captain order dan uang dari pelayan

b. Hitung bersama-sama uang yang diterima dari pelayan

c. Segera lakukan payment pada mesin POS.

d. Hitung kembali jika ada sisa pembayaran. 
e. Cetak Struk sebagai bukti sah pembayaran, yang wajib diberikan kepada pengunjung/pelanggan.

f. Simpan struk merah sebagai laporan ke bagian keuangan

Perlengkapan cashier :
a. Mesin POS ( point of sales)
b. Cash drawer
c. Printer
d. Mesin $E D C$
e. $C P U$
f. UPS
g. Kertas Struk Printer
h. Pulpen

5. Prosedur yang harus dilakukan oleh seorang penyaji

a. Persiapkan semua peralatan dan perlengkapan area pantry (sendok, garpu, piring, mangkuk )

b. Persiapkan semua menu.

c. Setelah semua perlengkapan dan menu lengkap info ke pelayan dan kasir bahwa semua menu komplit

Tugas Selanjutnya adalah Menerima

Captain Order dari kasir berikut prosedur yang harus dilaksanakan :

a. Menerima Captain Order dan kertas struk sementara dari kasir.

b. Pastikan Captain order dan kertas struk digabung

c. Baca dengan teliti, dan segera di prepare.

d. Untuk produk MTO (Made to order) segera hubungi bagian koki atau bar.

e. Jika pesanan sudah selesai, segera minta pelayan untuk mengantar pesanan pengunjung/pelanggan.

f. Ceklist kertas struk, sebagai tanda bahwa pesanan sudah selesai.

Berikut cara penyajian Menu di piring saji Untuk NASI CAMPUR

1. Metode $3 \mathrm{M}$ ( 1 nasi, 1 lauk, 1 sayur )

a. Gunakan piring kotak / Square Plate

b. Letakkan nasi di sudut $\pm 10 \mathrm{~cm}$ dari ujung piring

c. Letakkan sayur disebelah kanan, dengan bentuk memanjang kedepan

d. Kemudian untuk menu utama / lauk letakkan disebelah kiri memanjang.

2. Metode 4 M ( 1 nasi, 2 lauk, 1 sayur )

a. Gunakan piring kotak / Square Plate b. Letakkan nasi di sudut $\pm 10 \mathrm{~cm}$ dari ujung piring

c. Letakkan lauk pertama disebelah kanan, kemudian lauk kedua disebelah kiri, letakkan sayur diantara lauk. (sayur ditengah) atur sedemikian rupa sehingga tampak rapi

d. Jika pengunjung/pelanggan menghendaki sayur yang berkuah, letakkan sayur kedalam mangkok kecil, dan letakkan diantara kedua lauk.

Setelah pesanan pengunjung/pelanggan sudah selesai, berikutnya tugas Server yang harus mengantarkan pesanan pengunjung/ pelanggan, berikut prosedur yang harus dijalankan:

1. Gunakan tray saat mengantarkan pesanan pengunjung/pelanggan.

2. Letakkan tray diatas telapak tangan, pastikan posisi tray ditengah dan telapak tangan mampu membawa tray.

3. Posisi badan tegap, untuk menjaga keseimbangan.

4. Antar pesanan sesuai meja pesanan

5. Sebutkan menu yang dipesan oleh pengunjung/pelanggan, dan letakkan sesuai dengan pengunjung/pelanggan yang memesan makanan/minuman.

6. Untuk lebih meyakinkan pengunjung/ pelanggan, tanyakan kembali apakah masih ada pesanan yang kurang, jika ada sampaikan " mohon ditunggu sebentar, dan pesanan akan segera kami antar"

7. Selalu ucapkan " selamat menikmati, dan jika ada tambahan silahkan hubungi kami kembali"

6. Prosedur melakukan clear up dan Scrambing Table

a. Bersihkan meja dengan mengangkat equipment kotor yang sudah selasai digunakan.

b. Saat mengangkat peralatan jangan lupa mengatakan permisi.

c. Jangan mulai mengangkat peralatan jika masih ada pengunjung/pelanggan yang makan.

d. Dalam mengangkat peralatan kotor ikuti arah jarum jam dan pastikan tidak ada remah-remah yang tercecer.

e. Pastikan pengunjung/pelanggan telah mengijinkan sebelum membersihkan mejanya. 


\section{Hasil Penelitian}

Deskripsi hasil penelitian pada "Waroeng Makan Tepi Laut" ini dijelaskan pada Tabel 1.

Tabel 1. Hasil Penelitian

\begin{tabular}{|c|c|}
\hline $\begin{array}{l}\text { Faktor-faktor } \\
\text { Yang Diamati }\end{array}$ & Keterangan \\
\hline Bahan Baku & Mudah didapat, sebagian diperoleh diperoleh dari mitra kerja. \\
\hline Lokasi Usaha & Terletak ditempat yang strategis. \\
\hline Bangunan Usaha & Bangunan usaha miliki pribadi dari pengelola "Waroeng Makan Tepi Laut". \\
\hline Pilihan Menu & Menu yang disediakan "Waroeng Makan Tepi Laut” bervariasi. \\
\hline Harga & Patokan harga "Waroeng Makan Tepi Laut" dapat dijangkau. \\
\hline Pelayanan & $\begin{array}{l}\text { "Waroeng Makan Tepi Laut" memiliki karyawan yang ramah tamah, sopan santu dan } \\
\text { cukup berpenampilan rapih serta cepat dalam penyajian dan penataan makanan rapih. }\end{array}$ \\
\hline Ciri Khas Menu & "Waroeng Makan Tepi Laut" memiliki menu andalan yang digemari. \\
\hline Teknologi & $\begin{array}{l}\text { "Waroeng Makan Tepi Laut" menggunakan teknologi yang modern untuk menunjang } \\
\text { operasional. }\end{array}$ \\
\hline Lokasi Parkir & Lokasi parkir dari “Waroeng Makan Tepi Laut” cukuplah luas. \\
\hline Panggung Musik & Inovasi dari "Waroeng Makan Tepi Laut" untuk menarik pelanggan. \\
\hline Promosi Produk & Promosi produk dimuat disitus khusus "Waroeng Makan Tepi Laut". \\
\hline Layanan Pesan Antar & $\begin{array}{l}\text { Layanan pesan antar "Waroeng Makan Tepi Laut" belum evektif karena belum } \\
\text { mencakup seperempat dari Kawasan Mega Mas Manado. }\end{array}$ \\
\hline Cabang Usaha & $\begin{array}{l}\text { Waroeng Makan Tepi Laut" baru memiliki } 1 \text { cabang usaha yang berlokasi di Manado } \\
\text { Trend Center (MTC). }\end{array}$ \\
\hline Mitar Kerja & $\begin{array}{l}\text { Mitra kerja Waroeng Makan Tepi Laut terdiri dari: PT Surya Madistrindo, PT Niaga } \\
\text { Nusa Abadi, PT Sumber Cipta Mulitinaiga, PT Bantoel Distribusi Utama, PT Aneka } \\
\text { Sari, PT Mura Kristal Kawanua, PT Sinar Sosro, PT Putra Santoso, PT Japfa, PT Surya } \\
\text { Wenang Indah, UD Collton, PT Timur Jaya, Garuda 37, Pemasok pisang goroho, kelapa } \\
\text { muda, telur ayam dan gas LPG. }\end{array}$ \\
\hline Kebijakan Pemerintah & $\begin{array}{l}\text { "Waroeng Makan Tepi Laut" mengalami kesulitan dalam memperoleh bahan baku } \\
\text { ketika pemerintah menaikan harga bahan baku. }\end{array}$ \\
\hline $\begin{array}{l}\text { Berkembangnya Sektor } \\
\text { Pariwisata }\end{array}$ & $\begin{array}{l}\text { Dapat mengundang para Pelancong dan merupakan peluang bagi "Waroeng Makan Tepi } \\
\text { Laut" untuk memperkenalkan diri. }\end{array}$ \\
\hline
\end{tabular}

Ada pun hasil angket yang diperoleh dari 15 pengunjung/pelanggan yaitu:

\begin{tabular}{|c|c|c|c|c|}
\hline \multicolumn{5}{|c|}{ Tabel 2, Hasil Angket } \\
\hline \multirow{2}{*}{ Pertanyaan } & \multicolumn{3}{|c|}{ Pilihan Responden (pengunjung/penlanggan) } & \multirow{2}{*}{ Total } \\
\hline & (S) & (CS) & (TS) & \\
\hline Lokasi usaha strategis & 14 & 1 & - & $15 \mathrm{P} / \mathrm{P}$ \\
\hline Pilihan menu bervariasi & 10 & 5 & - & $15 \mathrm{P} / \mathrm{P}$ \\
\hline Harga menu terjangkau & 12 & 3 & - & $15 \mathrm{P} / \mathrm{P}$ \\
\hline Pelayanan & & & & $15 \mathrm{P} / \mathrm{P}$ \\
\hline Ramah tamah & 10 & 5 & - & \\
\hline Sopan santun & 9 & 6 & - & \\
\hline Penampilan & 7 & 8 & - & \\
\hline Kecepatan penyajian & 9 & 6 & - & \\
\hline Cara penyajian & 12 & 3 & - & \\
\hline Lokasi parkir & 7 & 7 & 1 & $15 \mathrm{P} / \mathrm{P}$ \\
\hline Panggung musik & 13 & 1 & 1 & $15 \mathrm{P} / \mathrm{P}$ \\
\hline
\end{tabular}

\section{Keterangan:}

S : Setuju

CS : Cukup Setuju

TS : Tidak Setuju

$\mathrm{P} / \mathrm{P} \quad$ : Pengunjung/Pelanggan 


\section{Analisis Faktor Internal dan Eksternal}

Faktor internal merupakan faktor yang dapat dikendalikan oleh perusahan. Sedangkan faktor eksternal merupakan kondisi dimana perusahan tidak dapat atau sedikit mengendalikannya. Berikut faktor internal dan eksternal yang dimiliki oleh "Waroeng Makan Tepi Laut":

\section{Faktor Internal}

1. Bahan Baku "Waroeng Makan Tepi laut"

Bahan baku merupakan aspek yang sangat penting agar dapat menghasilkan suatu produk yang dapat dikonsumsi. Untuk bahan baku yang digunakan oleh usaha ini berdasarkan hasil wawancara dengan pihak yang terkait terdiri dari: beras, lauk pauk berupa daging bebek, ayam, daging sapi, ikan laut, ikan air tawar dan sayur-mayur serta rempah-rempah yang terdiri dari cabe, tomat, bawang merah, bawang putih, bawang bombai, kemangi daun lemon dan rempah-rempah lainnya. Bahan baku beras didatangkan dari Kotamobagu, daging bebek dan ayam diperoleh dari pemasok dan untuk daging sapi, ikan laut, ikan air tawar, sayur-mayur serta rempah-rempah diperoleh dari pasar.

Kendala yang dihadapi oleh "Waroeng Makan Tepi laut" dalam memperoleh bahan baku ketika bahan baku yang dibutuhkan tidak diperoleh atau hanya mendapatkan sebagian dari apa yang dibutuhkan. Hal ini membuat pengelolah mengambil kebijakan untuk tidak menyediakan menu tersebut pada hari itu atau menyediakan setengah dari bahan yang diperoleh.

\section{Lokasi Usaha "Waroeng Makan Tepi laut"}

Berdasarkan hasil wawancara dengan menggunakan kuesioner kepada 15 responden (pengunjung/pelanggan "Waroeng Makan Tepi laut") 14 dari 15 responden mengatakan bahwa lokasi dari tempat makan ini sangatlah strategis dan sisanya memilih lokasi cukup strategis.

\section{Bangunan Usaha "Waroeng Makan Tepi laut"}

Bagunana usaha "Waroeng Makan Tepi laut" merupakan bangunan milik sendiri dari pengelolah yang diperoleh dari pihak PT Mega Mas. Bangunan yang terdiri dari 2 ruko dan 4 lantai ini awalnya akan digunakan pengelolah sebagai kantor untuk menginfentori barang- barang pada usahanya yang lain, akan tetapi dirubah menjadi rumah makan dengan mengandalkan keterampilan memasak sang isteri.

\section{Pilihan Menu}

Pilihan menu yang disediakan oleh "Waroeng Makan Tepi laut" bervariasi, berdasarkan hasil wawacara terhadap 15 responden 10 mengatakan bervariasi dan sisanya cukup bervariasi. Hal ini membuktikan "Waroeng Makan Tepi laut" menyediakan banyak variasi menu yang membuat pengunjung/pelanggan bebas memilih menu apa yang diinginkan dengan rasa menu yang beragam.

\section{Harga Menu}

Harga dari tiap-tiap menu berdasarkan hasil wawancara kepada pelanggan, 12 dari 15 responden mengatakan bahwa harga dapat terjangkau sedangkan sisanya cukup terjangkau.

"Waroeng Makan Tepi Laut" menyediakan pelayanan di mana para pengunjung/pelanggan dapat melihan dan memesan langsung menu apa yang diinginkan atau mengisi sendiri pada daftar menu yang diperoleh dari server. Ada pun kualitas pelayanan dari "Waroeng Makan Tepi Laut" berdasarkan data angket dari 15 pengunjung/pelanggan:

a. Ramah tamah, 10 pengunjung/pelanggan mengatakan ramah dan sisinya cukup ramah.

b. Sopan santun, 9 pengunjung/pelanggan mengatakan sopan santun dan sisanya cukup sopan santun.

c. Penampilan, 7 pengunjung/pelanggan mengatakan pemanpilan dari para karyaman "Warong Makan Tepi Laut" rapih dan sisinya cukup rapih.

d. Kecepatan penyajian, dari data angket 9 pengunjung/pelanggan mengatakan penyajian dari "Waroeng Makan Tepi Laut" cepat dan sisanya cukup cepat.

e. Cara penyajian, penyajian makan dari "Waroeng Makan Tepi Laut" dari hasil angket 12 mengatakan penataan makannya rapih dan sisinya cukup rapih.

\section{Ciri Khas Menu.}

"Waroeng Makan Tepi Laut" memiliki ciri khas menu yang paling banyak digemari 
oleh pengunjung/pelanggan yang datang berkunjung baik makanan maupun minuman dan snack. Adapun menu yang paling banyak disukai oleh pengunjung/pelanggan, dari hasil wawancara dengan 15 responden (pengunjung/pelanggan) yaitu paket bebek smart, paket sambal manis, paket mujair pepes, paket ikan bakar, peket cakalang rica, paket abon cakalang, peket tindarong woku, nasi goreng polong, jus alvokad, ice teh, kopi hitam, kopi susu, choco blast with oreo, es campur, the hangat, mineral water, blue punch, indomie goreng dan pisang goroho.

\section{Teknologi yang digunakan.}

Teknologi yang digunakan oleh "Waroeng Makan Tepi Laut" merupakan teknologi yang cukup modern. Berdasarkan hasil wawancara dengan pihak pengelolah sistem cashier yang digunakan oleh usaha ini merupakan sistem yang didatangkan dari Kota Surabaya. Peralatan memasak yang digunakan juga sebagian telah diganti dengan mesin hal ini dikatakan agar proses produksi dari "Waroeng Makan Tepi Laut" cepat dan mudah.

\section{Lokasi parkir.}

Dari hasil wawancara menggunakan kuesioner kepada 15 responden, 7 responden mengatakan lokasi parkir Waroeng Makan Tepi Laut luas, 7 responden cukup luas dan 1 responden mengatakan tidak luas. Dari hasil ini diketahui bahwa lokasi parkir "Waroeng Makan Tepi Laut" dapat dikatakan cukup luas, hal ini juga didukung karena Waroeng Makan Tepi Laut yang berada didalam kawasan Mega Mas.

\section{Panggung Musik}

Panggung musik yang dilaksanakan setiap malam Sabtu dan Minggu di Waroeng Makan Tepi Laut dapat menarik perhatian dari pengunjung/pelanggan. Panggung musik yang baru dibuka pada bulan Agustus 2015 ini merupakan inovasi dari pengelolah untuk menarik konsumen dan terbukti dari 15 responden yang diwawancarai 13 responden menyetujui adanya panggung musik ini, sisanya 1 responden cukup setuju dan 1 responden tidak setuju.

\section{Promosi Produk.}

Promosi produk dari "Waroeng Makan Tepi Laut" sudah dapat dikatakan cukup evektif, di mana promosi produk ini dimuat di halaman situs khusus "Waroeng Makan Tepi Laut", dan bulan lalu baru ulang di muat dikoran. Promosi ini selalu dilakukan oleh pihak manajer dan karyawan "Waroeng Makan Tepi Laut" yang dimuat juga pada situs pridadi dari karyawan.

\section{Layanan Pesan Antar.}

Layanan pesan antar "Waroeng Makan Tepi Laut" belum dapat dikatakan cukup, mengapa karena belum mencakup seperempat dari kawasan Mega Mas. Layanan pesan antar di "Waroeng Makan Tepi Laut" baru mencakup ke ruko-ruko terdekat. Ada pun pada cabang usaha "Waroeng Makan Tepi Laut" yang terletak di Manado Trend Center (MTC) baru melayani pesan pada kios-kios didalam Mall dan belum sampai keluar Mall.

\section{Sarana Pra-sarana.}

Untuk sarana pra sarana "Waroeng Makan Tepi Laut" yang digunakan untuk operasional sudah cukup memadai, untuk kendaraan terdiri dari 1 buah kendaran sepeda motor, 1 buah kendaraan sepeda motor besar (Viar) dan ditambah kendaraan (mobil) milik pengelolah. Sedangkan untuk sarana pra sarana peralatan dapur juga lengkap dengan penggunaan yang praktis, begitu juga dengan perlengkapan lainnya berupa telphone, TV dll.

\section{Cabang Usaha.}

"Waroeng Makan Tepi Laut" baru memiliki 1 cabang usaha yang terletak didalam Manado Trend Center (MTC). Dari wawancara dengan pihak pengelolah mengatakan bahwa Waroeng Makan Tepi Laut akan menambah cabang usaha baru di lokasi lain. Aspek-aspek yang ada diatas dapat menjadi kekuatan tersendiri dari "Waroeng Makan Tepi Laut" untuk mengembangkan usahanya baik dilokasi yang terdekat maupun yang jauh.

\section{Faktor Eksternal}

1. Mitra Kerja

"Waroeng Makan Tepi Laut" membangun mitar kerja agar mudah memperoleh bahan baku. Selain itu "Waroeng Makan Tepi Laut" juga memperoleh perlengkapan lainnya berupa asbak, tempat sampah dll dari mitra kerjanya dengan distributor rokok. Adapun mitra kerja dari 
Waroeng Makan Tepi Laut antara lain: C.V. AKE ABADI (pemasok air mineral), PT Surya Madistrindo, PT Niaga Nusa Abadi, PT Sumber Cipta Multiniaga, PT Bantoel Disrtibui Utama (pemasok rokok), PT Aneka Sari (pemasok the celup, bumbu ayam), PT Mura Kristal Kawanua (pemasok es kristal), PT Sinar Sosro (pemasok the botol sosro), PT Putra Santoso (pemasok daging bebek), PT Japfa (pemasok daging ayam), PT Surta Wnang Indah (pemasok mayonais), UD Collton (pemasok tissue, sabun cuci piring, sedotan, sterofoom), PT Timur Jaya (pemasok kecap, marjan, soklin lantai), Garuda 37 (pemasok air isi ulang), pemasok kelapa muda, pemasok pisang goroho, pemasok telur ayam, pemasok gas LPG.

\section{Pesaing}

"Waroeng Makan Tepi Laut" memiliki begitu banyak pesaing. Berkembangnya usaha sejenis dan pendatang baru membuat "Waroeng Makan Tepi Laut" harus memiliki lebih banyak inovasi dan mampu bersaing agar dapat memperahankan loyalitas dari pengunjung/pelanggan "Waroeng Makan Tepi Laut". Salah satu inovasi yang dilakukan oleh pengelolah "Waroeng Makan Tepi Laut" yaitu life musik yang menghadirkan salah satu pemusik asal Jakarta yaitu basis Boomerang untuk bermain di panggung musik "Waroeng Makan Tepi Laut". Selanjutnya "Waroeng Makan Tepi Laut" menghadirkan Band Good Blash dan kesempatan ini digunakan oleh pengelolah "Waroeng Makan Tepi Laut" untuk mempromosikan menu baru yaitu nasi goreng polong.

\section{Kebijakan Pemerintah}

Kebijakan pemerintah mengambil bagian dalam harga bahan pangan, membuat "Waroeng Makan Tepi Laut" juga akan mengalami kesulitan dalam menperoleh bahan baku, seperti harga beras yang naik di pasaran, harga BBM yang naik dll, ini membuat pengelolah Waroeng Makan Tepi Laut juga berusaha mengimbangi agar "Waroeng Makan Tepi Laut" tetap memberikan yang terbaik bagi pengunjung/palanggan terhadap permintaan akan produk dari Waroeng Makan Tepi Laut.

\section{Berkembangnya Sektor Pariwisata}

Berkembangnya sektor pariwisata yang dapat mengundang para pelancong dari dalam dan luar Negeri merupakan peluang yang besar bagi "Waroeng Makan Tepi Laut" untuk memperkenalkan diri. Ciri khas yang dimiliki oleh "Waroeng Makan Tepi Laut" dapat dijadikan modal agar usaha ini dapat diketahui oleh masyarakat luas sehingga dapat membantu dalam proses pengembangan usaha.

\section{KESIMPULAN DAN SARAN}

\section{Kesimpulan}

Dari hasil penelitian yang diperoleh bahwa pengembangan "Waroeng Makan Tepi Laut" memiliki peluang yang besar dalam mengembangkan usaha. Faktor-faktor yang berpengaruh pada pengembangan usaha baik internal maupun eksternal dimana faktor-faktor dapat menjadi pendorong maupun penghambat terhadap pengembangan usaha dari "Waroeng Makan Tepi laut".

Faktor pendorong "Waroeng Makan Tepi laut" terdiri dari: lokasi usaha, pilihan menu, harga, ciri khas menu, pelayanan (ramah tamah, sopan santun, keepatan penyajian, dan cara penyajian), panggung musik, mitra kerja dan berkembangnya sektor pariwisata.

Faktor penghambat atas pengembangan usaha "Waroeng Makan Tepi laut" terdiri dari: bahan baku, pelayanan (penampilan), lokasi parkir, pesaing dan kebijakan pemerintah. Dari faktor-faktor ini dapat diketahui bagaimana "Waroeng Makan Tepi laut" dapat berkembang dan juga hasil angket yang diberikan kepada para pelanggan/pengunjung dapat ditarik kesimpulan dimana:

1. "Waroeng Makan Tepi laut" memiliki lokasi usaha yang strategis,

2. Pilihan menu dari "Waroeng Makan Tepi laut" bervariasi,

3. Harga yang ditawarkan oleh "Waroeng Makan Tepi laut" dapat terjangkau,

4. Kualitas pelanyanan yang dimiliki "Waroeng Makan Tepi laut" cukup baik,

5. Memiliki ciri khas menu yang disukai oleh para pelanggan/pengunjung,

6. Memiliki lokasi parkir yang cukup luas, dan

7. Panggung musik yang disukai oleh para pelanggan/pengujung.

Keadaan yang dimiliki "Waroeng Makan Tepi Laut" sudah dapat dikatakan baik untuk pengembangan usaha karena usaha ini memiliki faktor pendorong baik dari internal mampu eksternal yang mendorong perkembangan usaha dengan menggunakan strategi yang tepat. 


\section{Saran \\ "Waroeng Makan Tepi Laut"} memiliki faktor internal dan ekternal yang berpengaruh oleh sebab itu "Waroeng Makan Tepi laut" harus mampu menekan faktor yang berpengaruh negatif dan memaksimalkan faktor yang dapat berpengaruh positif terhadap usaha dengan menghadirkan inovasiinovasi baru. Adapun saran bagi "Waroeng Makan Tepi Laut":

1. "Waroeng Makan Tepi laut" harus mampu mengendalikan faktor-faktor yang berpengaruh terhadap usaha baik positif maupun negatif sehingga dapat berkembang lagi dan cabang usaha ini ada dimana-mana.

2. "Waroeng Makan Tepi Laut" harus dapat memambah lagi kualitas pelanyanannya agar dapat mempertahankan loyalitas pelanggan/penggunjung.

3. "Waroeng Makan Tepi Laut" dapat memambah atau memperbaiki sarana dan pra sarana yang dimiliki.

4. "Waroeng Makan Tepi Laut" harus dapat mengikuti selera pelanggan/pengunjung dan tren pasar.

\section{DAFTAR PUSTAKA}

Chambers. 1995. Essential English Dictionary. Chambers Harrap Publisher

Harsana, M. Widayati, T, M. 2004. Analisis Pasar Ditinjau Dari Persepsi Wisatawan Terhadap Kuliner Di Kabupaten Sleman. Universitas Negeri Yogyakarta. Yogyakarta.

Hendro. 2011. Dasar-dasar kewirausahaan. Erlangga. Jakarta Timur

Kumesan, J, T. 2015. Strategi Bertahan hidup (Live Survival Strategy) Buruh Tani Di Desa Tombatu Dua Utara Kecamatan Tombatu Utara. Skripsi S-1. Jurusan Sosial Ekonomi. Fakultas Pertanian. Universitas Sam Ratulangi. Manado.
Lazuardi, A. 2008. Formulasi Strategi Pengembangan Usaha Restoran Macaroni Panggan (MP) Bogor. Program Sarjana Ekstensi Manajemen Agribisnis. Fakultas Pertanian. Institute Pertanian Bogor. Bogor.

Masengi, G. 2014. Analisis Keuntungan Usaha Rumah Makan El-Shadai Di Kawasan Wisata Kuliner "Wakeke Manado". Jurusan Sosial Ekonomi. Fakultas Pertanian. Universitas Sam Ratulangi. Manado.

Mukmin, A, TS. Suryono, A. Said, A. Implementasi Rencana Strategi Pemerintah Dalam Pengembangan Usaha Batik Tulis Tenun Gedog (Studi Di Dinas Perekonomin Dan Pariwisata Kabupaten Tuban Dan Di Usaha Batik Tulis Tenun Gedog Di Desa Kedungrejo Kecamatan Kerek Kabupaten Tuban. Jurusan Adninistrasi Publik. Fakultas Ilmu Administrasi. Universitas Brawijaya. Malang. Jurnal Administrasi Publik (JAP), Vol 1, No 6, Hal 11311140

Oroh, C, G. 2007. Strategi Pengembangan PT Multi Nabati Sulawesi sebagai Industri Inti pada Klapper Kelapa di Sulawesi Utara. Jurusan Sosial Ekonomi. Fakultas Pertanian. Universitas Sam Ratulangi. Manado.

Parma, G, P, I. 2012. Formulasi Strategi Pengembangan Usaha Masakan Lokal Sebagai Produk Wisata Kuliner Di Kabupaten Buleleng. Program Magister. Program Studi Kajian Pariwisata. Program Pasca Sarjana. Universitas Udayana Denpasar. Bali

Peraturan Menteri Perdagangan RI No 07/MDag/Per/2/2013 Tentang Pengembangan Kemitraan Dalam Waralaba Untuk Jasa Makanan dan Minuman. 
Puspitasari, K, N. 2015. Strategi Pengembangan Agroindustri Berbasis Biji Kakao di Desa Poyuyanan Kecamata Passi Barat Kabupaten Bolaang Mongondow. Skripsi S-1. Jurusan Sosial Ekonomi. Fakultas Pertanian. Universitas Sam Ratulangi. Manado.

Rangkuti, F. 2009. Analisis SWOT Teknik Membedah Kasus. Cetakan ke-1. PT Gramedia Pustaka Utama. Jakarta.
Robinson, P. 1997. Manajemen Strategi Formulasi, Implementasi dan Pengendalian. Jilid 1. Binarupa Aksara. Jakarta.

Rochman. F. 2011. Strategi Pengembangan Bisnis PT Ojid Kharisma Nusantara. Program Studi Agribisnis. Fakultas Sains dan Teknologi. Universitas Islam Negiri Syarif Hidayatullah. Jakarta

Wiyono, H, E. 2007. Kamus Besar Bahasa Indonesia. Palanta. Jakarta 